Journal of Teacher Education for Sustainability, vol. 23, no. 1, pp. 132-149, 2021

\title{
Enhancing Ecocentric Environmental Attitudes: An Experience of Science Teaching to Inspire Students to Value Trees
}

\author{
Maria Eduarda Ferreira \\ Higher School of Education, Communication and Sport, CI\&DEI, \\ Polytechnic of Guarda, Guarda, Portugal \\ Rui Pitarma \\ CISE - Electromechatronic Systems Research Centre, \\ University of Beira Interior, Covilhã, Portugal
}

\begin{abstract}
Deforestation is a global issue. Education has a fundamental role to play in this context. In this regard, the direction and effectiveness of educational practices should focus on the empowerment of students in ecocentric environmental attitudes. A key point in education for environmental sustainability is pedagogical approaches focused on the development of critical and reflective thinking. In this context, objectified research was developed in the (re)conceptualization of the "living being", with thermogram didacticization, as a way to develop egalitarian feelings of the need for similar attitudes among living beings. The study was developed in an action-research context. The pedagogicaldidactic intervention was within the scope of the "Natural Sciences" curricular unit of the "Basic Education" degree at a Portuguese Institution. After a pedagogical-didactic intervention, the reconceptualization of "living being" was observed in these students, presenting, now, a reflexive argument concerning the ecocentric environmental attitudes regarding the "living being" - the tree vs. animal, highlighting the importance that the thermographic images had in the (re)significance of their "new look" regarding the tree.
\end{abstract} Key words: ecocentric environmental attitudes, tree, science teaching, thermogram, image

\section{Introduction}

The ecosphere has undergone major and rapid changes, in which deforestation, the lack of care and protection of the tree are included. The loss of the world's forests is a problem of local and global concern. Forests are vital in the ecosphere. Without trees, drought becomes more frequent and the maintenance of watersheds, water retention in the soil, floods, landslides are real problems and, too often, with catastrophic outcome in the lives of communities and completely altering natural ecosystems. The ecosystems we all need, and are dependent on, are affected by our actions and choices (Hofman- 
Bergholm, 2018, p. 27). All individuals should be aware of this environmental impact and have the skills (knowledge, abilities, attitudes, and values) to lead to the necessary and urgent change. There is a need for changes in thoughts and actions in the educational system (Hofman-Bergholm, 2018). In an age of technological development, Fedosejeva et al. (2018) highlight the need to develop critical thinking and creativity in young people. Education has a fundamental role to play in this context, as stated by UNESCO (2019). The environmental problems should be part of the focus of science teaching (Silva et al., 2020), i.e., directed towards sustainability (Gadotti, 2008). There is a need to renew the teaching of biology, as environmental issues require approaches in which there is a connection between theoretical knowledge and critical and reflective systematisation (Brito \& Araújo, 2020). Developing ecocentric skills, in a formal context, direct teaching towards experience, reflection and action within the framework of education for responsible citizenship. Since skills cannot be taught, as they need to be developed (UNESCO, 2015; Wiek et al., 2011), the professor plays a crucial role in this process. "Educators are powerful change agents who can deliver the educational response needed" (UNESCO, 2017, p. 51). The demands of Education for Sustainable Development (ESD) need teachers with a lifelong learning culture (Mardapi \& Herawan, 2019). The teacher's profile must be teacher-research (Alves, 2020).

In Agenda 21, Chapter 36 reads, "Education is critical for promoting sustainable development and improving the capacity of the people to address environment and development issues", "programs should promote a greater awareness of environmental issues" and "education is indispensable to changing people's attitudes so that they can assess and address their sustainable development concerns" (UNESCO, 1992). ESD is about building a better tomorrow for everyone - and it should start today (UNESCO, 2019). The ESD is focused on building active citizenship (Chen \& Liu, 2020; Cheeseman et al., 2019). It is shared, "Education for another possible world will necessarily be education for sustainability" (Godotti, 2000, p. 105). The ESD is concerned with attitudes and dispositions affecting behavior (UNESCO, 2015). "If education is the solution, then it requires a deeper critique and a broader vision for the future" (UNESCO, 2005, p. 59). There is a causal relationship between environmental literacy and the environmental impacts associated with behaviors (Roth, 1992). The development of students' critical literacy, perhaps, will contribute to making individuals not only wiser but also better (Shortland, 1988). If "environmental literacy involves human discourse about inter-relationships with the environment, it is essentially the degree of our capacity to perceive and interpret the relative health of environmental systems and to take appropriate action to maintain, restore, or improve the health of those systems" (Roth, 1992, p. 14). Then learning must have social importance, so scientific literacy and environmental citizenship are interconnected. The current environmental problems associated with the relationship between human and nature entered current education. Therefore, the causes of Anthropocene problems constitute global challenges and require a pedagogical response (Salite et al., 2021). In this context, we are positioned to promote science education in the context of science teaching.

This focuses on a science teaching process that promotes transformative learning, expecting that teachers are facilitators of students' learning (Gottlieb et al., 2013). The focus is on enabling students to question and change the way they see and think about the world, to deepen their understanding (Lotz-Sisitka et al., 2015; Slavich \& Zimbardo, 
2012; Mezirow, 2000). The professor will have to be a facilitator of the development of learning and add value to previous experiences and conceptions. The professor creates/ provides the contexts that promote the development of skills and challenges/motivates students to change their views of the world and to be critical, reflective, and interventional. Naturally, this teaching process is a learner-centered approach (Barth, 2015), with students being autonomous in the construction of knowledge and the professor being a mediator of the development of learning. Learner-centered pedagogy has the potential for quality education (Scweisfurth, 2015; Jónsdóttir, 2015). "Critical and reflective thinking is also a key method for learning for the SDG” (UNESCO, 2017, p. 55), placing science teaching within the scope of education for responsible citizenship. Environmental literacy is interlinked with knowledge, attitude, sensitivity, and concern (Veisi et al., 2018). Approaches and teaching methodologies on environmental sustainability certainly involve reflection and research on educational practices. Research on how to teach and learn also means understanding the effectiveness of technological resources and teaching methodologies that involve and focus the student on the learning process (Ferreira et al., 2019). Ferreira et al. (2019) assessed the educational potential of thermograms in the (re)conceptualization of "living being" to inspire children to act for the protection of the tree. Based on these results, this study aims to assess the potentialities of a teaching strategy (Figure 1) in the development of ecocentric environmental attitudes, to the tree, with a class university students. The pedagogical-didactic intervention was developed in the "Natural Sciences" classes of the degree in "Basic Education".

\section{Research Question and Objective}

The study sought an answer to the following research question:

Is the didactic exploration of thermograms based on reflexive questioning effective in the learning of the concept of "living being" with the meaning of biological similarity between tree and animal and, consequently, the development of similar ecocentric environmental attitudes?

The objective of the study was to assess a pedagogical-didactic intervention based on the reflexive questioning and using the thermograms (tree vs. animal) in the didactic exploration.

\section{Theoretical Background}

\section{Education Practices and Environmental Attitudes}

Teaching that the tree is a "living being", which needs to be preserved, is a pedagogical objective of the curricular contents of "Natural Sciences" at any level of education. The relevance of the learning also needs the link to today environmental issues. Already in 1998, Ilga Salite emphasized the role of teachers in the "implementation of an ecocentric paradigm". The anthropocentric and simplistic vision has contributed to global environmental issues (Luz et al., 2018). The educational process should develop skills that provide individuals with critical and creative capacity, based on respect for differences and synchronized with an active role in the exercise of environmental citizenship. Education for another possible world will necessarily be education for sustainability (Gadotti, 
2000). Studies show the importance of developing attitudes in promoting pro-environmental behaviors (Thompson \& Barton, 1994; Weigel \& Weigel, 1978). By 2030, all learners are to acquire the knowledge and skills needed to promote sustainable development (UNESCO, 2017). The attitudes are long-lasting and loaded with affectivity (pro or con), predisposing to an action coherent with the knowledge and affections about an entity/object (Rodrigues, 1998). They can be considered a learned predisposition to respond (pro or con) consistently to a given object. Behavioral intention is the immediate determinant/indicator of motivation and the best predictor of this behavior. If there is a manifestation of behavioral intention and necessary skills, then the occurrence of the behavior is very likely (Fishbein, 2004). The attitude is expressed by evaluative responses that may be behavioral or behavioral intentions (Fishbein, 2004; Holland et al., 2002; Armitage \& Christian, 2003) and, in general, everything can be the object of attitude (Lima, 2002).

Environmental attitudes are "perceptions or beliefs related to the physical environment, including factors that affect its quality" (APA, 2001, p. 89). Such attitudes can be manifested through pro-environmental behavior (Hernández \& Hidalgo, 1998). Environmental attitudes can be ecocentric and anthropocentric. In both these types of attitudes, there is an environmental concern and interest in preserving nature; however, the reasons for this concern and environmental interest are different (Thompson \& Barton, 1994). The motivational basis of anthropocentrism is in the effects that environmental problems have on the quality of human life, so it is urgent to preserve nature for the benefit of mankind. In ecocentrism, Man is seen as an intrinsic element to nature, belongs to and values it (Schultz, 2002).

If "education is the action we take on the people who make up society, to train them in an integral, conscious, efficient and effective way, which allows them to form a value of the acquired contents, meaning them in a direct link with their daily lives, to act consequently from the assimilated educational process" (Calleja, 2008, p. 109), then the teaching processes must accompany the demands and the individual needs of societies, countries and the world. Education and learning systems are perceived as failing to keep up with the pace of change, let alone leading the change (UNESCO, 2017). In this context, scientific knowledge must be integrated with the knowledge of reality and its problems, as well as developing a sense of responsibility and the ability to interpret, criticize, judge, decide and intervene responsibly in the immediate environment. It can be said that learning science is also awakening to the construction of a more solidary society, with an ecocentric view of the nature-society reality. Thus, teaching science is a process that should also prioritize the development of ecocentric environmental attitudes.

The development of scientific literacy inseparable from the attitudinal dimension of environmental citizenship (Ferreira \& Dias, 2018; Ferreira et al., 2019) requires learning with social relevance in the context of education for responsible citizenship. The way the professor positions him/herself and understands education will determine the teaching and learning process s/he develops and the learning developed is not inseparable from this process. When significant practices are experienced in the classroom, there are opportunities to relate knowledge to social reality.

There are several aspects to which the professor should pay special attention in guiding his/her educational practice. The development of critical-reflexive thinking (why it is so; what to do; how to do it; always learning) and student involvement (in the 
psychomotor, cognitive and affective domain) are aspects that require reflection and commitment to action. Reflective positioning in the way it is taught, scrutinizing all the stages of the teaching and learning process is, perhaps, the path to follow. Many references seek to (re)guide this process. The serious environmental problems impose very significant demands on the educational practice, and professors are expected to (re)think and (re)guide their action on how they teach science and understand how their students are learning what they teach.

If we want to develop reflexive-criticality, the teacher must have it as well (Libâneo, 2006). "Teaching for reflection and the development of critical thinking is teaching that creates the conditions for this type of thinking in practical contexts" (Litwin, 2000, p. 194). Developing critical-reflective teaching requires developing skills and attitudes in the student necessary for reflection. As a rule, what happens is that "we are concerned that our students learn knowledge, information, develop intellectually, with little regard for the development of their human and professional skills and their values of professionals and citizens committed to the problems and the evolution of their society" (Masetto, 2003 , p. 28). Science teaching cannot make "Science" as a rhetoric of conclusions (Cachapuz et al., 2004).

\section{Images $v s$ Thermograms}

Naturally, in any teaching and learning process, didactic resources, if properly exploited, are tools that facilitate, motivate and stimulate science education. In a society, like ours, where information is strongly associated with the image, this resource is in everyday life, becoming included in the teaching and learning process. At the level of Science, it appears that it communicates through real scientific images and schematics. Science teaching uses technologies to simplify and teach these real images of Science. The images, as didactic resources, play a fundamental role in the constitution of scientific ideas and their conceptualization (Martins et al., 2005). However, images to constitute an effective learning resource need the mediation of the professor. The images alone do not guarantee to be a tool for raising awareness and critical (re)construction of reality and scientific knowledge. The images, in the classroom, lack didactic use, i.e., their didactic potential lacks the mediation of the professor. If the image has a communicative potential, it should be called a semiotic image (Kress \& Van Leeuwen, 1996). It is in this context that the thermogram may have pedagogical value if explored with the mediation of the professor (Ferreira et al., 2019). The infrared thermography technology allows observing peculiarities/physiological characteristics - temperature - in living beings, as in the case of the tree, not perceived by the "naked eye" (Vidal \& Pitarma, 2019; Pitarma et al., 2019). Based on the thermal radiation emitted by the objects, this technique allows for the evaluation of their surface temperature (Holst, 2002). In general, trees produce low metabolic heat when compared to animals (Monteith \& Unsworth, 2007) and, therefore, not detectable without Infrared Thermography Technology (IRT). The thermographic camera captures the infrared radiation emitted (Gadotti, 2000; Roth, 1992; Barth, 2015) observable in the thermograms (Vidal \& Pitarma, 2019; Pitarma et al., 2019).

Through egalitarian/ecocentric environmental attitudes towards all "living beings", it is believed to constitute the "path to be followed towards the goal" - enhancement of the tree and thus protection of the forests. 
In primary education, the "research highlighted the potential of thermograms (images) as a didactic resource in the development of children's ecocentric education" (Ferreira, André, \& Pitarma, 2019, p. 19). This pedagogical-didactic intervention aims to understand the potential of the pedagogical-didactic exploration of thermograms in the environmental education of university students.

\section{Research Methodology}

The study fits into a constructivist paradigm, "to understand one must interpret", i.e., "knowing is not passive, but active" (Schwandt, 1994). It was developed in a research-action context, an essentially practical and applied research methodology, which is governed by the need to solve real problems (Cohen, Manion, \& Morrison, 2000; Coutinho et al., 2009) and in which the researcher is involved in the change strategies and evaluates the intervention effect (Perrenoud, 1980; Bogdan \& Biklen, 2010; Pardal \& Lopes, 2011). This is experiential education research since the construction of educational knowledge is at the basis of the subject educational action (Trilla Bernets, 2007). In this context, an educational practice was developed, framed in a pedagogical-didactic intervention, seeking the learning of the concept of "living being" with the meaning of biological similarity between the tree and animal and, consequently, the development of similar ecocentric environmental attitudes.

\section{Study Participants}

The participants $(n=26)$ were all Portuguese students of the degree in "Basic Education" of a public higher education institution.

\section{Data Analysis}

The main data collection techniques used were observation (Sousa, 2009), direct and participant, and the analysis of records produced by students (Tables 1 and 3). Analysis of the results covered the categories: "teaching methodology and didactic resources" and "students" perception of thermograms".

\section{Pedagogical Approach}

The intervention (Figure 1) has been developed within the curricular unit "Natural Sciences”. It took place for three weeks (five classes). 
Figure 1

Conceptual Scheme of Pedagogical-Didactic Intervention

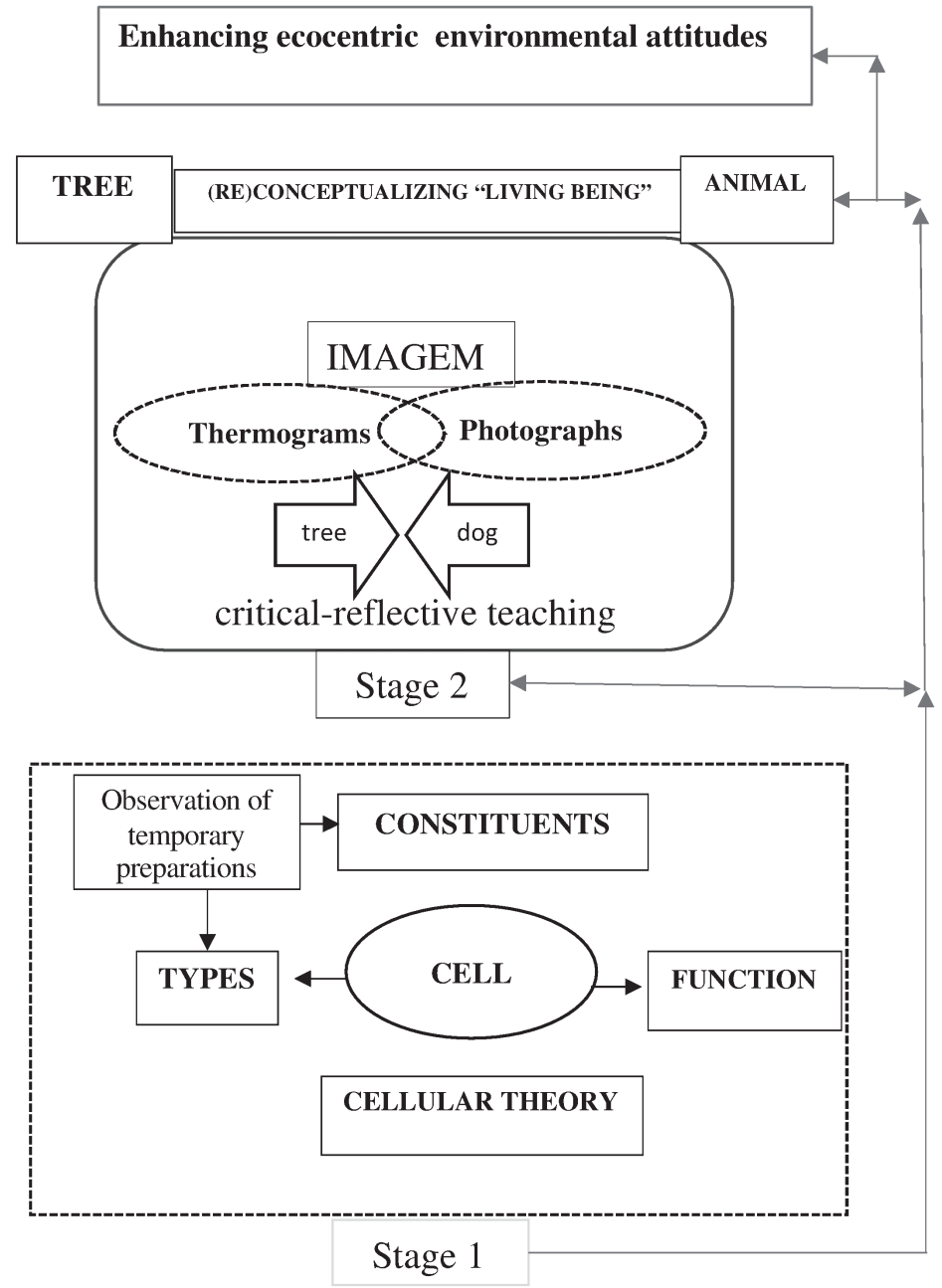

The educational practice (Stage 2) that used thermograms and photographs was developed in the "Natural Sciences" laboratory and lasted for three hours. This educational practice was organized into six sequential steps (Figure 2). Before this class (Stage 1): there were 3 theoretical classes on "cell" (each class $=3 \mathrm{~h}$ ) and 1 laboratory class $(3 \mathrm{~h})$ to observe temporary preparations of cells of the Phaseolus vulgaris leaf and the lingual epithelium. In the following theoretical class $(2 \mathrm{~h})$, the first hour was dedicated to listening to students about their assessment of the relevance they attributed to thermograms in their learning about the tree. 
Figure 2

Educational Practice Steps (Six Steps)
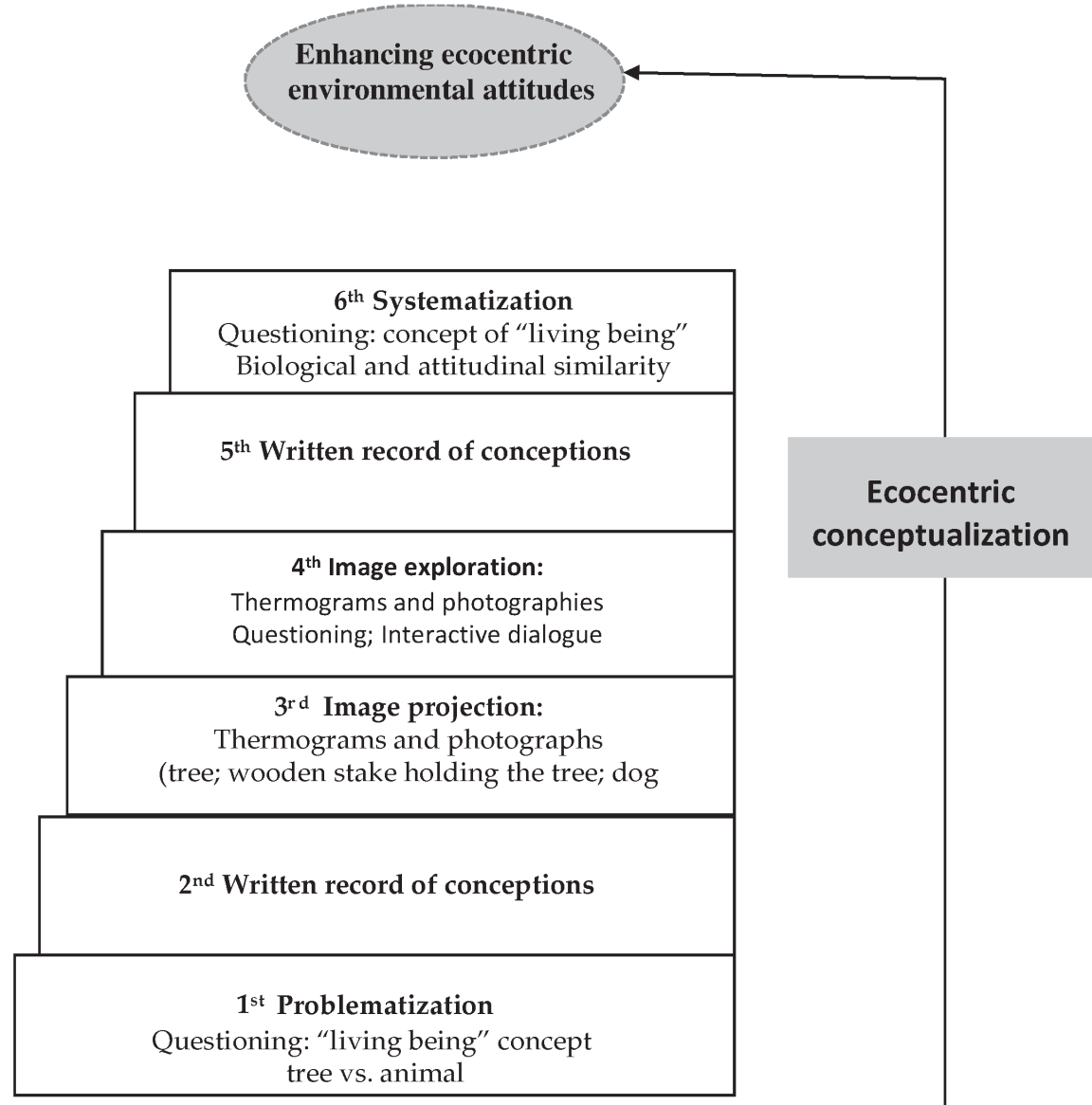

(RE)CONCEPTUALIZING “LIVING BEING”

As in the usual laboratory classes, students work in groups of two, the option to keep this work routine.

The class started with the question: What is a "living being"?

Each group discussed and presented the concept. All associated "living being" as constituted by the cell and considered it to be the unit: functional, structural and hereditary. The question followed: Is there a biological similarity between the tree and the animal, for example, the dog?

Next, we requested that, individually, they presented, in writing, the reasons for their positioning. We clarified that the concept records in this class would be anonymous.

After collecting the records, a photograph of a dog and a tree was projected (Figure $3 \mathrm{a}$ and $\mathrm{b})$. Sequentially, the following questions were asked:

$1^{\text {st }}$ : Are they both living beings? 
Figure 3

Photograph (a) of a Dog and a Tree (b) (Prunus Domestica L)

(a)

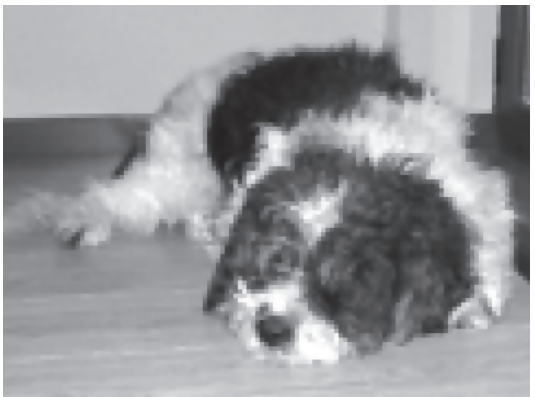

(b)

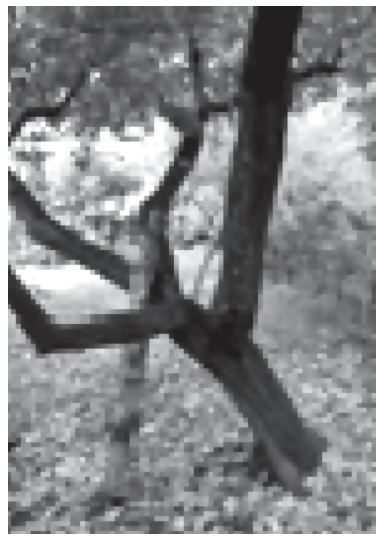

They unanimously agreed that they were and presented arguments similar to the answer to the first question.

$2^{\text {nd }}$ : Can we conclude that there is a biological similarity between these living beings?

This questioning triggered an emotional interactive dialogue, between students, with arguments in favor of "yes" and arguments justifying "no".

The Professor assumed a passive attitude, only managing and directing the instigating questioning.

$3^{\text {rd }}$ : This was followed by the characterization of the thermographic machine.

$4^{\text {th }}$ : The question is: Do you know this technical equipment?

Everyone said they did not.

$5^{\text {th }}$ The operation of the equipment was characterized.

$6^{\text {th }}$ : Then, a PowerPoint with two thermograms was projected (Figure $4 \mathrm{a}-\mathrm{b}$ ): one for the $\operatorname{dog}$ and the other for the tree with a support stake (lifeless tree trunk).

\section{Figure 4}

IRT Thermograms: (a) Dog; (b) Tree (Prunus Domestica L) With a Wooden Stake That Supports It

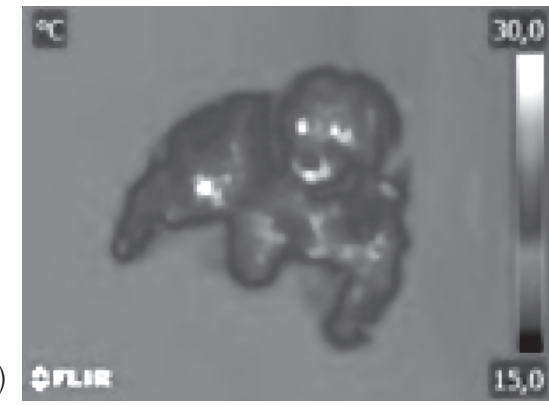

(b)

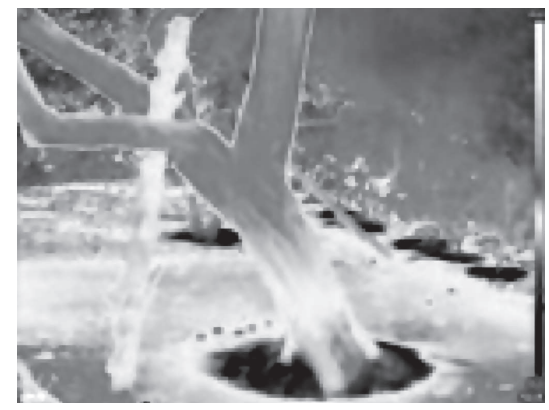


$7^{\text {th }}$ : The biological characteristics/meaning of what was observed in thermographic images were explored: it was questioned whether they understood the meaning of what they observed in thermograms. Compare the thermogram of the dog with that of the tree. In Figure 3, the differences between the "tree" - being alive - with the wooden stake holding the tree (where there is no life) are analyzed.

$8^{\text {th }}$ : We returned to the question: Is there a biological similarity between these living beings?

We requested the registration of the conceptions. We collected those records.

$9^{\text {th }}$ : Stimulating inter- and intra-group discussion, we then focused on questioning protective attitudes towards animals and trees.

Are your environmental attitudes the same/similar towards these beings?

It was requested to present, in writing, the convictions, of each one, about their attitudes, justifying their position.

Records were collected. The class ended with the promise that in the next theoretical class there would be a reflection (self and hetero) about the experience lived in this class.

\section{Results}

From the exploration of the biological characteristics/meaning of what was observed in the thermographic images: it was observed that none of them expressed understanding of the thermograms. It was the mediating attitude of instigation on the part of the professor that triggered curiosity and interest in understanding what was being projected. They showed an attitude of astonishment regarding the comparison between the dog, the "tree" - a living being - and the wooden stake holding the tree (Figure $4 \mathrm{a}$ and b). "It is unequivocal, the tree is a true living being", they referred with enthusiasm.

The analysis of the students' records (Table 1) on the question: Is there a biological similarity between the tree and the animal, for example, the dog?

\section{Table 1}

Students' Records on the Question: Is There a Biological Similarity Between the Tree and the Animal, for Example, the Dog?

\begin{tabular}{lll}
\hline \multirow{2}{*}{$\begin{array}{l}\text { Analysis aspects } \\
\text { (animal vs. tree) }\end{array}$} & \multicolumn{1}{c}{$\begin{array}{c}\text { Conceptions before didactic } \\
\text { exploration }\end{array}$} & \multicolumn{1}{c}{$\begin{array}{c}\text { Conceptions after didactic } \\
\text { exploration }\end{array}$} \\
\cline { 2 - 3 } $\begin{array}{l}\text { Biological } \\
\text { similarity }\end{array}$ & $\begin{array}{l}\text { Unanimity in the argument: both } \\
\text { are living beings. They resort to } \\
\text { the cell constitution argument. } \\
\text { Everyone claims that there is no } \\
\text { biological similarity. 15 of the } \\
\text { students argue, as a justification, } \\
\text { the lack of mobility of the tree. }\end{array}$ & $\begin{array}{l}\text { Everyone says they now think diffe- } \\
\text { rently. A statement is transcribed } \\
\text { "with the thermograms I concluded } \\
\text { that after all there is not that much } \\
\text { difference between animals and plants, } \\
\text { after all they all are livings". }\end{array}$ \\
$\begin{array}{l}\text { Environmental } \\
\text { attitudinal } \\
\text { similarity }\end{array}$ & $\begin{array}{l}\text { Everyone claims to have different } \\
\text { attitudes. The environmental } \\
\text { attitudes shown are anthropo- }\end{array}$ & $\begin{array}{l}\text { Everyone reveals an intention to } \\
\text { change attitudes. They show a predis- } \\
\text { position to ecocentric environmental } \\
\text { attitudes towards the tree. }\end{array}$ \\
\hline
\end{tabular}


Continuation of Table 1

The results concur that knowledge Two statements are transcribed: (living being) does not affect eco- "If we all had the opportunity to be centric attitudes.

Two statements are transcribed as an example "I have no affection for trees ... they are important for the production of oxygen."; "We have to protect them because sensitized concerning plants, we would certainly start to see them with different eyes, which is what happened here in our class today. Thank you for this teaching"; "I think that the world needs to see, like us, these without them we have no oxygen.” images so that habits change and that this living being has the life it deserves".

Records showed that the exploration of the thermograms triggered cognitive conflict about the meaning of "living being" concerning the tree and that this reconceptualization of "living being" had implications for the intention to change the environmental attitude. It is acknowledged that in this process the teacher shows complicity with innovation and commitment to action.

Based on direct observation, during the theoretical class, after the laboratory class, the records referring (Table 2 ) to the knowledge and attitudes evidenced by the "living being" tree are presented.

\section{Table 2}

\section{Observation of the Learning Outcomes}

\begin{tabular}{lcc}
\hline \multicolumn{1}{c}{ Analysis aspects (animal $v$ s. tree) } & $\begin{array}{c}\text { Concept of } \\
\text { "living being" }\end{array}$ & $\begin{array}{c}\text { Ecocentric } \\
\text { environmental } \\
\text { attitudes }\end{array}$ \\
\hline $\begin{array}{l}\text { Biological similarity meaning } \\
\text { Recognition of the relevance of the tree in ecosystems }\end{array}$ & $\mathrm{x}$ \\
$\begin{array}{l}\text { Recognition of the environmental impacts of deforestation } \\
\text { Social responsibility }\end{array}$ & $\mathrm{x}$ & $\mathrm{x}$ \\
$\begin{array}{l}\text { Involvement } \\
\text { Awareness of their proactive role }\end{array}$ & $\mathrm{x}$ \\
$\begin{array}{l}\text { Awareness of the implications of their attitudes on the } \\
\text { sustainability of the tree } v s \text {. the forest }\end{array}$ & $\mathrm{x}$ \\
Expression of intention to change attitudes & $\mathrm{x}$ \\
\hline
\end{tabular}

We found that the observation and exploration of the physiological characteristic "temperature", through the thermogram, changed the meaning/conception that these students had to "living being" and this reconceptualization had implications in their intentions to change attitudes.

To assess the potential of exploring thermograms in promoting ecocentric environmental attitudes towards the tree, through the (re)conceptualization of "living beings", as a way to inspire students to value trees, the analysis was carried out (Table 3 ) of the records of their perception. To this end, the records made after the exploration of the said images were analyzed, as well as the arguments explained, orally, in the theoretical class held after the laboratory educational practice. 
Table 3

Students' Records

\begin{tabular}{lll}
\hline Aspects of analysis & \multicolumn{2}{c}{ Conceptions after didactic exploration } \\
\cline { 2 - 3 } (domestic animal vs. tree) & \multicolumn{1}{c}{ Written records } & Observation \\
\hline Concept of "living being" & $\begin{array}{l}\text { They unanimously consider that thermograms } \\
\text { were responsible for changing the meaning } \\
\text { they attributed to the concept of "living } \\
\text { being". }\end{array}$ & $\begin{array}{l}\text { The plasmid was } \\
\text { confirmed in the } \\
\text { records. }\end{array}$ \\
$\begin{array}{ll}\text { Ecocentric environmental } \\
\text { attitudes }\end{array}$ & $\begin{array}{l}\text { They unanimously consider that thermograms } \\
\text { were responsible for changing attitudes. A } \\
\text { recurring statement is transcribed: "I became } \\
\text { aware that the tree is a living being and that it } \\
\text { needs care just like animals". }\end{array}$ & $\begin{array}{l}\text { The plasmid was } \\
\text { confirmed in the } \\
\text { records. }\end{array}$ \\
&
\end{tabular}

\section{Discussion}

Result analysis used the following categories: (i) teaching methodology and didactic resources; (ii) students' perception of thermograms.

The use of action research strategy showed to have a strong potential for adaptation and allowed us "to see the relationship between adaptive and innovative approaches" (Salite et al., 2021, p. 4).

\section{Teaching Methodology and Didactic Resources}

Records (Table 1) showed that the exploration of the thermograms triggered cognitive conflict about the meaning of "living being" concerning the tree and that this reconceptualization of "living being" had implications for the intention to change the environmental attitude. It is acknowledged that in this process the teacher shows complicity with innovation and commitment to action.

We found that the observation and exploration of the physiological characteristic "temperature", through the thermogram, changed the meaning/conception that these students had to "living being" and this reconceptualization had implications in their intentions to change attitudes. Having intention and the necessary skills, then the behavior is very likely (Fishbein, 2004; Holland et al., 2002; Armitage \& Christian, 2003). It appears that now, these students emphasized being sensitive to change their differentiated practices concerning the tree and the animal. The role of mediator and instigator that the professor played in the process was considered crucial. The discursive meditation must be intentional (Martins et al., 2005). In the pedagogical process that sought to be critical-reflexive (Libâneo, 2006; Litwin, 2000), the contexts provided allowed developing a significant educational practice, with implications in the (re)conceptualizing "living being" and, therefore, in ecocentric environmental attitudinal intentions. It was observed that the critical reflectiveness on the biological similarity between living beings - the tree vs. animals - triggered the need to change differentiated attitudes, of protection, concerning the tree, when compared with animals. These students were now sensitized and concerned with this "living being" - the tree. It is the conviction, with this educational practice, that the thermograms have a communicative/pedagogical potential to the (re)conceptualization of the "living being" tree. In the context of exploration followed 
(Figure 2), these thermograms are semiotic images. We consider that this technological resource (thermograms) constituted a valuable and promising pedagogical-didactic resource in the development of ecocentric environmental attitudes. Because, after these didactic explorations, a reflexive argument of concern to these living beings (trees) was observed in these students, highlighting the importance of images (thermograms) in the construction of this "new look" concerning the tree, making us believe, from now on, they would observe trees more closely and take on ecocentric environmental protective attitudes. The teaching process developed was a promoter of ecocentric education. In short, the overvaluation given to the articulation of science with society and the environment, through the didacticization of a technological resource (thermograms), allowed us to conclude that the teaching process developed, markedly reflective-critical, was effective, in these students, in the appropriation of environmental citizenship skills concerning the tree, concomitant with the content knowledge of "living being" (approach made in the theoretical classes that preceded, see Figure 1). The influence of educational action proposals depends on whether or not we believe (and to what extent) in their relative validity (Mcmurra, 1975), and the learning is shaped by the presentation of content (Sandri, 2019).

The teaching methodology supported by reflexive questioning, assuming the professor's mediating role, i.e., facilitator of students' learning (Gottlieb et al., 2013), in this educational practice (Figure 2), provided the context for the development of criticalreflexive (Libâneo, 2006; Litwin, 2000), propitiative of the development of ecocentric environmental attitudes. Research results also highlighted the effectiveness of the collaborative learning environment, focused on sharing conceptions and group reflection (Gillies, 2016). Without human and nature unit, we have the unsustainability of education. It is of crucial relevance to look to causes and solutions of Anthropocene problems (Salite et al., 2021). There is clearly a need for "a perspective in which sustainability is present in every human activity or experience” (ibid., p. 3). Our research findings highlight the contribution the science teaching-learning process can play in attaining such a purpose.

\section{Students' Perception of Thermograms}

The relevance was given by the students, during the theoretical class, to how much the thermograms had been fundamental for their "new look" concerning the tree. They reinforced how important it was for everyone to have the opportunity to see the thermographic images, as they found them inspiring/motivating so that behaviors could change and this living being (the tree) could "have the life it deserved". Thermograms revealed to be semiotic images (Kress \& Van Leeuwen, 1996) playing a fundamental role (Martins et al., 2005) in the conceptualization of "living being" applied to the tree. This finding obtained as a result of the research is similar to the results of the study with primary students where exploitation of thermograms had a positive effect on students' ecocentric environmental attitudes (Ferreira et al., 2019). In this educational practice, we find that "what you see is learned" and "what you see inspires you to change attitudes". But it must be emphasized that the image alone did not have meaning (Ferreira et al., 2019), and the role of mediator and instigator of the critical-reflexive discursive interaction, assumed by the professor during the operationalization of the teaching process, was crucial. The exploitation of thermograms should be regarded as a challenge to more traditional education and training process. 


\section{Conclusion}

In the educational practice developed, we found that the exploration of the physiological characteristic - temperature -, with the use of the thermographic image, allowed (re)signifying the concept of "living being" - tree. Inter- and intragroup interpretation, mediated by the professor, of the thermographic image, significantly provided the reconceptualization of "living being" (ecocentric conceptualization). In other words, the thermograms are didactic objects. The results indicate that the teaching methodology assuming the professor's mediating role provided the context for the development of critical-reflexive, propitiative of the development of ecocentric environmental attitudes. Knowing whether it is a right or wrong attitude to nature, it is to understand why it is wrong or right. This study can be taken as an example of the need to develop research on the outcomes regarding how to teach the "living being" concept. Our findings suggest that thermograms and teaching methodology development can positively contribute to developing ecocentric environmental attitudes.

There is a need for professors who are sensitized and motivated to develop innovation in science teaching. Developing skills of environmental citizenship should be part of the intentionality of the educational process of "Natural Sciences" curricular units, of any cycle of studies. To foster environmental attitudes means new approaches to "Natural Sciences" learning. This means moving beyond literacy to focus on the attitudinal dimension of environmental citizenship. The use of innovation in the teaching-learning process is the step to be taken by university teaching, the privileged locus for the reflection about the teaching-learning process innovation and development of new knowledge toward a sustainable world. The unsustainability relationship between human and nature on our planet lends urgency to the need to implement education for sustainability for the future. If students properly reflected on their values, especially on those related to the care about, most of the wicked environmental problems could be resolved. Effective action research is needed in the awareness of environmental issues, in particular in more and better research focusing on developing pedagogical approaches experienced by students. In the framework of education research towards ESD, the resource didactics in teaching practice is a research field that also needs more attention. Building active environmental citizenship increasingly needs a focus on the "modus operandi" of the science teacher, whatever the level of education. Developing ecocentric environmental attitudes in students requires that the teacher has pedagogical skills to link science teaching to real problems of our planet and the relationship between Man and Nature. This intentionality should be a guiding element of science teaching.

\section{Recommendations}

The experience of science teaching was carried out with 26 students; to observe the effect of educational practice on ecocentric attitude more clearly, the study should be conducted with larger groups of students. The size of the class is not necessarily a significant factor for the success of learning but help. In this study, the class size was small, and this was an advantage to develop the teaching and learning process in the class. 


\section{Acknowledgments}

The authors would like to thank João Crisóstomo for the technical support with the photos and thermograms.

Funding. The research has been funded by the National Funds through the FCT Foundation for Science and Technology, I.P., within the scope of the project Ref ${ }^{a}$ UIDB/ 05507/2020. Furthermore, we would like to thank the Centre for Studies in Education and Innovation (CI\&DEI) and the Polytechnic of Guarda for their support. It is framed in the activities of the project "TreeM - Advanced Monitoring \& Maintenance of Trees" No.023831, 02/SAICT/2016, co-funded by CENTRO 2020 and FCT within PORTUGAL 2020 and UE-FEDER structural funds.

\section{References}

Alves, F. R. V. (2020). A Didática Profissional (DP): implicações para a formação do professor e o ensino de disciplinas específicas no Brasil [The professional didactics (PD): Implications for teacher education and the teaching of specific disciplines in Brazil]. Revista Iberoamericana de Estudos em Educação, 15, 4, 1-22.

APA-American Psychological Association. (2001). Thesaurus of psychological index terms. American Psychological Association.

Armitage, C., \& Christian, J. (2003). From attitudes to behaviour: Basic and applied research on the theory of planned behaviour. Current Psychology: Developmental, Learning, Personality, Social, 22, 3, 187-185.

Barth, M. (2015). Implementing sustainability in higher education: Learning in an age of transformation. Routledge.

Bogdan, R. C., \& Biklen, S. K. (2010). Investigação qualitativa em educação: uma introdução à teoria e aos métodos. Porto editora.

Brito, L. T. S., \& Araújo, M. L. F. (2020). Professores de biologia e conflitos socioambientais: formação continuada em Suape-pe. Investigações em Ensino de Ciências, 25, 2, 259-271.

Cachapuz, A., Praia, J., \& Jorge, M. (2004). Da educação em ciência às orientações para o ensino das ciências: um repensar epistemológico. Ciência \& Educação, 10, 3, 363-38.

Calleja, J. M. R. (2008). Os professores deste século. Algumas reflexões. Revista Institucional Universidad Tecnológica del Chocó, 27, 1, 109-177.

Cheeseman, A., Wright, T. S. A., Murray, J., \& McKenzie, M. (2019). Taking stock of sustainability in higher education: A review of the police literature. Environmental Education Research, 25, 12, 1697-1712.

Chen, Shih-Yeh, \& Liu, Shiang-Yao. (2020). Developing students' action competence for a sustainable future: A review of educational research, Sustainability, 12, 4, 1374.

Cohen, L., Manion, L., \& Morrison, K. (2000). Research Methods in Education ( $5^{\text {th }}$ ed.). Routledge Falmer.

Coutinho, C. P., Sousa, A., Dias, A., Bessa, F., Ferreira, M. J., \& Vieira, S. (2009). Investigaçãoacção: Metodologia preferencial nas práticas educativas, Revista Psicologia, Educação e Cultura, 355-379. 
Fedosejeva, J., Boče, A., Romanova, M., Iliško, D., \& Ivanova, O. (2018). Education for sustainable development: The choice of pedagogical approaches and methods for the implementation of pedagogical tasks in the anthropocene age. Journal of Teacher Education for Sustainability, 20(1), 157-179.

Ferreira, M. E., André, A. C., \& Pitarma, R. (2019). Potentialities of thermography in ecocentric education of children: An experience on training of future primary teachers. Sustainability, 11(9), 2668.

Ferreira, M. E. R., \& Dias, H. (2018). Uma experiência na formação de futuros professores primários: Aprender sobre ambiente através do ensino das ciências [Training of future primary teachers: environment learning about environment when teaching sciences]. Revista Electrónica De Investigación En Educación En Ciencias, 2, 29-46.

Fishbein, M. (2004). Intentional behavior. In C. Spielberger (Ed.), Encyclopedia of Applied Psychology (pp. 329-334). Elsevier Academic Press.

Gadotti, M. (2008). Educar para a sustentabilidade: uma contribuição à década da educação para o desenvolvimento sustentável. Instituto Paulo Freire.

Gadotti, M. (2000). Perspectivas Atuais da Educação, Artes Médicas.

Gillies, R. M. (2016). Cooperative learning: Review of research and practice. Australian Journal of Teacher Education, 41(3).

Gottlieb, D., Vigoda-Gadot, E., \& Haim, A. (2013). Encouraging ecological behaviors among students by using the ecological footprint as an educational tool: A quasiexperimental design in a public high school in the city of Haifa. Environmental Education Research, 19, 844-863.

Hernández, B., \& Hidalgo, M. C. (1998). Actitudes y creencias hacia el medio ambiente. In J. I. Aragonés \& M. Amérigo (Orgs), Psicología ambiental (pp. 281-295). Pirámide.

Hofman-Bergholm, M. (2018). Changes in thoughts and actions as requirements for a sustainable future: A review of recent research on the finnish educational system and sustainable development. Journal of Teacher Education for Sustainability, 20, 2, 19-30.

Holland, R., Verplanken, B., \& Knippenberg, Ad. (2002). On the nature of attitudebehavior relations: The strong guide, the weak follow. European Journal of Social Psychology, 32, 869-876. doi: 10.1002/ejsp.135

Holst, G. C. (2002). Common sense approach to thermal imaging. SPIE - The International Society for Optical Engineering Bellingham.

Jónsdóttir, Á. (2015). Teaching and learning for sustainability: An Icelandic practicebased research. International Journal of Education Through Art, 11, 391-406.

Kress, G., \& Van Leeuwen, T. (1996). Reading images: The grammar of visual design. Routledge.

Libâneo, J. C. (2006). Reflexividade e formação de professores: outra oscilação do pensamento pedagógico brasileiro? In S. G. Pimenta \& E. Ghedin (orgs.), Professor Reflexivo no Brasil: gênese e crítica de um conceito (pp. 53-79). Cortez.

Lima, L. P. (2002). Atitudes: Estrutura e Mudança. In J. Vala \& M. B. Monteiro (Eds.), Psicologia social (pp. 187-225). Fundação Calouste Gulbenkian.

Litwin, E. (2000). Variações sobre a arte de narrar na aula universitária. In I. P. A. Veiga, M. E. L. M. Castanho (orgs.), Pedagogia universitária: a aula em foco (pp. 194212). Papirus. 
Lotz-Sisitka, H., Wals, A. E., Kronlid, D., \& McGarry, D. (2015). Transformative, transgressive social learning: Rethinking higher education pedagogy in times of systemic global dysfunction. Current Opinion in Environmental Sustainability, 16, 73-80.

Luz, R., Prudêncio, C. A. V., \& Caifa, A. N. (2018). Contribuições da educação ambiental crítica para o processo de ensino e aprendizagem em ciências visando à formação cidadã [Contributions of Critical Environmental Education to the process of teaching and learning in Sciences for citizen training]. Investigações em Ensino de Ciências, $23,3,60-81$.

Mardapi, D., \& Herawan, T. (2019). Community-based teacher training: Transformation of sustainable teacher empowerment strategy in Indonesia. Journal of Teacher Education for Sustainability, 21(1), 48-66.

Martins, I., Gouvêa, G., \& Piccinini, C. (2005). Aprendendo com imagens. Ciência e Cultura, 57, 4, 38-40.

Masetto, M. T. (2003). Competência pedagógica do professor universitário. São Paulo: Summus.

Mcmurra, Y. F. (1975). Concepts of mind and intelligence in educational theory. Educational Theory, 25, 234-242.

Mezirow, J. (2000). Learning as transformation: Critical perspectives on a theory in progress. Jossey-Bass.

Monteith, J. L., \& Unsworth, M. H. (2007). Principles of environmental physics ( $3^{\text {rd }}$ ed.). Academic Press.

Pardal, L., \& Lopes, E. S. (2011). Métodos e técnicas de investigação social. Areal Editores.

Perrenoud, P. (1981). Recherche et Implication dans le Changement. Service de la Recherche Sociologique.

Pitarma, R., Crisóstomo, J., \& Ferreira, M. (2019). Contribution to trees health assessment using infrared thermography. Agriculture, 9, 171. doi: 10.3390/agriculture 9080171

Rodrigues, A. (1998). Psicologia Social. Vozes Editora.

Roth, C. E. (1992). Environmental literacy: Its roots, evolution, and directions in the 1990s. Columbus/OH: ERIC Clearinghouse or Science, Mathematics and Environmental Education.

Salite, I. (1998). An ecocentric paradigm: An important tool for teachers os environmental education. Australian Journal of Environmental Education, 14, 81-85.

Salite, I., Fjodorova, I., \& Ivanova, O. (2021). Does the JTES help us create deeper personal meanings for sustainable education?. Journal of Teacher Education for Sustainability, 22(1), 1-6.

Sandri, O. (2021). Providing a 'point of entry': Approaches to framing sustainability in curriculum design in Higher Education. Australian Journal of Environmental Education, 37(1), 56-68.

Schultz, P. W. (2002). Inclusion with nature. In P. Schmuck \& W. P. Schultz (Eds.), Psychology of sustainable development (pp. 61-78). Kluwer Academic Publishers.

Schwandt, T. (1994). Constructivist, interpretivist approaches to human inquiry. Handbook of Qualitative Research, Thousand Oaks, California: Sage.

Schweisfurth, M. (2015). Learner-centred pedagogy: Towards a post-2015 agenda for teaching and learning. International Journal of Educational Development, 40, 25926. 
Shortland, M. (1998). Advocating science: Literacy and public understanding. Impact of Science on Society, 38, 305-316.

Silva, C. S. S., Prochnow, T. R., Pellegrini, G., \& Bizzo, N. (2020). Pesquisa de Percepções de Estudantes do Ensino Médio sobre os Desafios Ambientais [A survey of high school students' perceptions about environmental challenges]. Ciência \& Educação (Bauru), 26, e20020.

Slavich, G. M., \& Zimbardo, P. G. (2012). Transformational teaching: Theoretical underpinnings, basic principles, and core methods. Educational Psychology Review, 24, 4, 569-608.

Sousa, A. B. (2009). Investigação em educação (2a ed.). Lisboa: Livros Horizonte.

Thompson, S. C. G., \& Barton, M. A. (1994). Ecocentric and anthropocentric attitudes toward the environment. Journal of Environmental Psychology, 14, 149-157.

Trilla Bernets, J. (2007). Educational discourse and educational practice. Encouters on Educationa, 8, 127-142.

UNESCO. (1992). Agenda 21. https://sustainabledevelopment.un.org/content/ documents/Agenda21.pdf

UNESCO. (2017). Education for Sustainable Development Goals: Learning Objectives. http://unesdoc.unesco.org/images/0024/002474/247444e.pdf

UNESCO. (2017). Future Competences and the Future of Curriculum. http://www.ibe. unesco.org/sites/default/files/resources/02_future_competences_and_the_future_ of_curriculum_30oct.v2.pdf

UNESCO. (2015). Rethinking education. Towards a global common good? https://unevoc.unesco.org/e-forum/RethinkingEducation.pdf

UNESCO. (2019). Roadmap for Implementing the Global Action Programme on Education for Sustainable Development. http://unesdoc.unesco.org/images/0023/002305/ 230514e.pdf

UNESCO. (2005). UN Decade of Education for Sustainable Development 2004-2005. UNESCO.

Veisi, H., Lacy, M. G., Mafakheri, S., \& Razaghi, F. (2018). Assessing environmental literacy of university students: A case study of Shahid Beheshti University in Iran. Applied Environmental Education \& Communication, 1(18), 25-42.

Vidal, D., \& Pitarma, R. (2019). Infrared thermography applied to tree health assessment: A review. Agriculture, 9, 156.

Weigel, R., \& Weigel, J. (1978). Environmental concern: The development of a measure. Environment and Behavior, 10, 3-15.

Wiek, A., Withycombe, L., \& Redman, C. L. (2011). Key competencies in sustainability: A reference framework for academic program development. Sustainability Science, 6(2), 203-218.

Correspondence concerning this article should be addressed to Maria Eduarda Ferreira, Professor, Higher School of Education, Communication and Sport, Polytechnic of Guarda, Avenida Dr. Francisco Sá Carneiro, No. 50, 6300-559 Guarda, Portugal. Email: eroque@ipg.pt 